\title{
ANALISIS KETERAMPILAN PROSES SAINS DAN SIKAP ILMIAH PESERTA DIDIK KELAS XI MATA PELAJARAN BIOLOGI DI SMA AL-AZHAR 3 BANDAR LAMPUNG
}

\author{
Serly Guswita ${ }^{1}$, Bambang Sri Anggoro ${ }^{2}$, Nukhbatul Bidayati Haka ${ }^{3}$, Akbar Handoko $^{4}$ \\ 1,2,3,4 Universitas Islam Negeri Raden Intan Lampung \\ e-mail: Nukhbatul.bidayati7@gmail.com
}

Diterima : 12 November 2018. Disetujui: 29 November 2018. Dipublikasikan: 20 Desember 2018

\begin{abstract}
ABSTRAK
Kurangnya kemampuan keterampilan proses sains dan sikap ilmiah akan menyulitkan peserta didik memahami pelajaran Biologi itu sendiri. Hal ini terjadi pada peserta didik kelas XI SMA Al-Azhar 3 Bandar Lampung, mereka belum sepenuhnya memahami konsep Biologi. Penelitian ini bertujuan untuk mengetahui bagaimana profil Keterampilan Proses Sains yang dominan muncul di dalam praktikum biologi kelas XI IPA di SMA Al-Azhar 3 Bandar Lampung; bagaimana profil Sikap Ilmiah yang dominan muncul didalam praktikum biologi kelas XI IPA di SMA Al-Azhar 3 Bandar Lampung, dan bagaimana hubungan Keterampilan Proses Sains dan Sikap Ilmiah dalam pembelajaran biologi. Penelitian ini merupakan penelitian kualitatif deskriptif. Sampel yang digunakan sebanyak 3 kelas yang dipilih dengan teknik acak kelas, yaitu kelas XI IPA 2, kelas XI IPA 5 dan kelas XI IPA 6. Teknik pengumpulan data yang digunakan adalah tes, observasi, angket dan dokumentasi. Teknik analisis data penelitian ini menggunkan data reduction (reduksi data), data display (Penyajian data), dan consclusion drawing/verivication (kesimpulan). Hasil penelitian ini adalah profil Keterampilan Proses Sains yang dominan muncul yaitu mengajukan pertanyaan, mengamati/observasi, merencanakan percobaan, dan melakukan percobaan, sikap ilmiah yang dominan muncul yaitu mengutamakan bukti, menerima perbedaan dan bersikap positif terhadap kegagalan, dan hubungan Keterampilan Proses Sains dan Sikap Ilmiah yakni membantu peserta didik memahami konsep pembelajaran biologi.
\end{abstract}

Kata kunci: Biologi, proses sains, Sikap lmiah.

\begin{abstract}
The lack of ability of science process skills and scientific attitudes will make it difficult for students to understand the Biology lesson itself. This happened to the eleventh grade students of Al-Azhar 3 High School in Bandar Lampung, they did not fully understand the concept of Biology. This study aims to find out how the dominant profile of Science Process Skills appears in biology practicum in class XI IPA at Al-Azhar 3 High School Bandar Lampung, how the profile of the dominant Scientific Attitude appears in the biology practicum of class XI IPA at Al-Azhar 3 High School Bandar Lampung, and how is the relationship between Science Process Skills and Scientific Attitudes in biology learning. This research is a descriptive qualitative study. The samples used were 3 classes selected by class random technique, namely class XI IPA 2, class XI IPA 5 and class XI IPA 6. Data collection techniques used were tests, observations, questionnaires and documentation. The data analysis technique of this study uses data reduction (data reduction), data display (data presentation), and consclusion drawing / verification (conclusion). The results of this study are the profile of the dominant Science Process Skills that arises, namely asking questions, observing / observing, planning experiments, and conducting experiments, the dominant scientific attitude that arises is prioritizing evidence, accepting differences and being positive towards failure, and the relationship between the Science Process Skill and the Scientific Attitude namely helping students understand the concept of biological learning.
\end{abstract}

Keywords: Biology, science process, scientific attitude. 


\section{PENDAHULUAN}

Pendidikan memegang peranan yang sangat penting dalam kehidupan, karena pendidikan merupakan proses perubahan sikap dan tingkah laku seseorang (Puspita, Yetri, dan Novianti 2017; Karyanti dan Komarudin 2017). Pendidikan merupakan kebutuhan pokok bagi setiap manusia, karena dengan adanya pendidikan manusia dapat terus belajar dan memahami berbagai macam masalah serta akan dapat mencapai tujuan serta kesejahteraan hidupnya, sehingga manusia dapat mengembangkan potensi dirinya agar dapat mengatasi permasalahan dan memnuhi kebutuhan hidupnya yang akan datang (Septina, Farida, dan Komarudin 2018). Pembelajaran biologi atau sains merupakan salah satu cabang ilmu sains yang mengkaji tentang makhluk hidup dan komponen-komponen penyusunnya (Puspita, Supriadi, dan Pangestika 2018). Pembelajaran sains setidaknya mengandung empat hal yaitu, konten atau produk, proses atau metode, sikap dan teknologi (Rustaman dkk. 2005). Tanwil menyatakan bahwa hakikat pembelajaran biologi itu berisikan tentang sikap berupa rasa ingin tau tentang benda, fenomena alam, makhluk hidup, serta hubungan sebab akibat yang menimbulkan masalah baru yang dapat dipecahkan melalui prosedur yang benar, juga mengenai proses berupa prosedur pemecahan masalah melalui metode ilmiah, yang menghasilkan produk berupa fakta, prinsip, teori, dan hukum, serta aplikasi berupa penerapan metode ilmiah dan konsep IPA dalam kehidupan sehari-hari (Novitasari, Ilyas, dan Amanah 2017).

Keterampilan proses sains merupakan kemampuan peserta didik dalam menerapkan metode ilmiah dalam memahami, mengembangkan sains serta menemukan ilmu pengetahuan. Keterampilan proses sains sangat penting bagi setiap peserta didik sebagai bekal untuk menggunakan metode ilmiah dalam mengembangkan sains untuk memperoleh pengetahuan baru atau mengembangkan pengetahuan yang dimiliki. Keterampilan Proses Sains (KPS) adalah metode ilmiah yang didalamnya melatihkan langkah-langkah untuk menemukan sesuatu melalui eksperimen dan percobaan. KPS tidak hanya diberikan kepada peserta didik di tingkat dasar dan menengah bahkan diperguruan tinggi. Keterampilan Proses Sains tediri atas sejumlah keterampilan yaitu mengamati (Observasi), menafsirkan pengamatan (Interprestasi), mengelompokkan (Klasifikasi), meramalkan (Prediksi), melakukan komunikasi, mengajukan pertanyaan, mengajukan hipotesis, merencanakan percobaan, menggunakan alat dan baan, menerapkan konsep, serta melaksanakan percobaan (Rustaman dkk. 2005; Arumsari, Rosilawati, dan Kadaritna 2016). Tidak hanya itu secara garis besar bahwa keterampilan proses juga merupakan pendekatan proses 
dalam pengajaran ilmu pengetahuan alam didasarkan atas pengamatan terhadap apa yangdilakukan oleh seorang ilmuwan.

Pengembangan Keterampilan Proses Sains, memerlukan penyesuaian antara metode pembelajaran yang digunakan dengan Keterampilan Proses Sains yang akan dikembangkan. Pemilihan metode yang tepat diharapkan dapat menimbulkan pengaruh untuk memunculkan kemampuan keterampilan proses sains peserta didik. Metode pembelajaran tersebut menuntut peserta didik untuk aktif.

Keterampilan Proses Sains sangat berkaitan dengan Sikap Ilmiah karena didalam pembelajaran biologi Sikap Ilmiah harus dimiliki oleh setiap peseta didik yang akan melakukan kerja ilmiah seperti pengamatan, observasi, mengkomunikasikan, mengukur dll. Dimana kerja ilmiah tersebut merupakan suatu Keterampilan Proses Sains yang tentunya didukung oleh adanya sikap terbuka, berpikir kritis, bebas dari penyimpangan, menghargai pendapat orang lain, mempertahankan kejujuran, kesabaran, ketelitian, kecermatan serta kedisiplinan yang merupakan bagian dari sikap ilmiah yang harus dilakukan oleh peserta didik. Sikap ilmiah merupakan salah satu dari tujuan pembelajaran biologi yang hendak dicapai. Sikap ilmiah juga merupakan salah satu dari kaidah-kaidah keilmuan dalam melaksanakan otonom keilmuan. Arthur A. Carin mengukapkan enam indikator sikap ilmiah yaitu: (1) rasa ingin tahu; (2) mengutamakan bukti; (3) skeptis/ tidak mudah percaya; (4) menerima perbedaan; (5) dapat bekerja sama; dan (6) bersikap positif terhadap kegagalan (Marlina 2013; Saputra, Anggraeni, dan Supriatno 2016; Sukaesih 2011; Mintania, Su'aidy, dan Dasna 2013).

Karakteristik sikap ilmiah, yaitu mengembangkan keingintahuan tentang lingkungannya, percaya bahwa setiap akibat ada sebabnya, mempunyai pandangan terbuka, seperti halnya Depdiknas menyebutkan bahwa sikap ilmiah yang penting dikembangkan didalam pembelajaran karena dapat melatih sikap berani dan santun dalam mengajukan pertanyaan dan berargumentasi, ingin tahu, peduli lingkungan, mau bekerja sama, terbuka, tekun, cermat, kreatif, dan inovatif, kritis, disiplin, jujur, objektif, dan beretos kerja tinggi. Keterampilan Proses Sains ini perlu dikembangkan, sebab Keterampilan Proses Sains dalam mata pelajaran Biologi sangat diperlukan, sebagai wujud dalam pendidikan Ilmu Pengetahuan Alam. Seiring dengan jalannya proses sains itu akan terbentuk sikap ilmiah peserta didik seperti jujur, teliti, objektif, bertanggung jawab dan dapat bekerja sama dengan orang lain. Keterampilan proses sains ini dapat memberikan siswa pengertian yang 
tepat tentang hakikat ilmu pengetahuan, memberikan kesempatan kepada siswa bekerja dengan ilmu pengetahuan, membuat siswa belajar proses dan produk ilmu pengetahuan ${ }^{1}$.

Berdasarkan hasil wawancara yang ada diketahui bahwa guru di S M A Al-Azhar 3 Bandar Lampung menyadari bahwa kegiatan praktikum merupakan suatu pembelajaran yang sangat penting untuk dilakukan namun didalam penerapannya ada beberapa kendala yang dihadapi seperti saat ini ruang laboratorium masih dalam tahap renovasi, namun guru tetap berupaya melaksanakan praktikum meski dilakukan diluar laboratorium. Didalam praktikum yang telah dilakukan Beberapa indikator Keterampilan Proses Sains telah dilaksanakan seperti halnya mengamati, melakukan pengklasifikasian, melakukan komunikasi, serta menggunakan alat dan bahan. Serta di dalam pengaplikasian Sikap Ilmiah juga telah dilakukan seperti halnya peserta didik harus teliti dalam melakukan pengamatan, bersikap jujur, terbuka, disiplin, peduli terhadap lingkungan yang memang sudah di upayakan didalam praktikum yang dilaksanakan tetapi selama ini hal-hal yang berkaitan dengan itu semua tidak direkam dalam suatu instrumen yang terencana.

\section{METODE PENELITIAN}

Metode penelitian yang peneliti gunakan merupakan penelitian kualitatif. Penelitian kualitatif adalah penelitian yang digunakan untuk meneliti pada kondisi objek alamiah dimana peneliti merupakan instrumen kunci. ${ }^{2}$ Jenis penelitian yang digunakan dalam penelitian ini adalah penelitian deskriptif. Penelitian deskriptif adalah penelitian yang meneliti sekelompok manusia, suatu objek, atau suatu kelas, tujuannya adalah untuk membuat gambaran secara fakta, akurat, dan sistematis. Penelitian ini termasuk kedalam penelitian deskriptif yang dilakukan untuk mendapatkan data dari persoalan-persoalan yang konkrit di lapangan berupa informasi berbentuk kalimat yang memberi gambaran tentang Keterampilan Proses Sains dan Sikap Ilmiah yang dimiliki oleh peserta didik. Dimana penelitian ini dilakukan untuk menggambarkan atau menjelaskan secara sistematis, faktual dan akurat mengenai fakta dan sifat populasi untuk daerah tertentu ${ }^{3}$. Instrumen penelitian yang akan digunakan sebagai berikut:

\footnotetext{
1 Muh. Tawil, liliasari, Loc.cit. h.43

${ }^{2}$ Sugiyono, Metode Penelitian Kuantitatif dan Kualitatif dan R\&D (Bandung: Alfabeta, 2014. h. 35)

${ }^{3}$ Wina Sanjaya, Penelitian Pendidikan: Jenis, Metode dan Prosedur (Jakarta: Kencana Prenada Media Group, 2013, h. 33)
} 
Tabel 1

Instrumen Penelitian Dan Tujuan Penggunaan Instrumen

\begin{tabular}{|c|c|c|c|c|c|}
\hline No. & $\begin{array}{c}\text { Jenis } \\
\text { Instrumen }\end{array}$ & Tujuan Instrumen & $\begin{array}{c}\text { Bentuk } \\
\text { Instrumen }\end{array}$ & $\begin{array}{l}\text { Sumber } \\
\text { Data }\end{array}$ & Waktu \\
\hline $\begin{array}{l}1 \\
.\end{array}$ & $\begin{array}{l}\text { Tes dengan menggun } \\
\text { akan posttest) } \\
\text { Keterampilan Proses } \\
\text { Sains. }\end{array}$ & $\begin{array}{l}\text { - Mendeskripsikan dan } \\
\text { menganalisis } \\
\text { Keterampilan Proses } \\
\text { Sains pada saat } \\
\text { sebelum dan sesudah } \\
\text { pembelajaran pada } \\
\text { materi sistem } \\
\text { pencernaa dan sistem }\end{array}$ & $\begin{array}{l}\text { Soal } \\
\text { multiple } \\
\text { choice }\end{array}$ & $\begin{array}{l}\text { Peserta } \\
\text { didik }\end{array}$ & $\begin{array}{l}\text { Pada awal akhir } \\
\text { kegiatan } \\
\text { praktikum }\end{array}$ \\
\hline $\begin{array}{l}2 \\
.\end{array}$ & $\begin{array}{l}\text { Lembar Observasi } \\
\text { Keterampilan Proses } \\
\text { Sains. }\end{array}$ & $\begin{array}{l}\text { Menganalisis } \\
\text { Keterampilan Proses } \\
\text { Sains peserta didik } \\
\text { pada saat } \\
\text { pelaksanaan kegiatan } \\
\text { praktikum. }\end{array}$ & $\begin{array}{l}\text { Lembar } \\
\text { observasi } \\
\text { dengan } \\
\text { semua } \\
\text { indikator } \\
\text { keteramp }\end{array}$ & $\begin{array}{l}\text { Peserta } \\
\text { didik }\end{array}$ & $\begin{array}{l}\text { Selama proses } \\
\text { praktikum } \\
\text { berlangsung. }\end{array}$ \\
\hline $\begin{array}{l}3 \\
.\end{array}$ & Angket Sikap Ilmiah. & $\begin{array}{l}\text { Mendeskripsikan } \\
\text { sikap ilmiah peserta } \\
\text { didik saat mengikuti } \\
\text { praktikum sistem } \\
\text { sistem pencernaan } \\
\text { dan sistem } \\
\text { pernapasan. }\end{array}$ & $\begin{array}{l}\text { Skal likert } \\
\text { dengan } \\
30 \text { item } \\
\text { pernyatan } \\
\text { Menggunak } \\
\text { an semua } \\
\text { indikator } \\
\text { sikap }\end{array}$ & $\begin{array}{l}\text { Peserta } \\
\text { didik }\end{array}$ & $\begin{array}{l}\text { Pada akhir } \\
\text { kegiatan } \\
\text { praktikum }\end{array}$ \\
\hline 4 & Catatan lapangan & $\begin{array}{l}\text { - Menggambarkan } \\
\text { kegiatan dan } \\
\text { Keadaan } \\
\text { pembelajaran yang } \\
\text { berlangsung }\end{array}$ & $\begin{array}{l}\text { Catatan } \\
\text { harian }\end{array}$ & Peneliti & $\begin{array}{l}\text { Selama } \\
\text { penelitian } \\
\text { Berlangsung }\end{array}$ \\
\hline
\end{tabular}

\section{HASIL PENELITIAN}

Berdasarkan penelitian yang telah dilaksanakan di Laboratorium IPA di SMA AlAzhar 3 Bandar Lampung Tahun Ajaran 2017/2018. Didapatkan rekap hasil rekapitulasi data hasil observasi tiap ragam keterampilan proses sains beserta persentasenya diperlihatkan pada tabel dibawah ini : 


\section{Data Tingkat Penguasaan Keterampilan Proses Sains}

\begin{tabular}{|c|c|c|c|c|c|}
\hline \multirow[b]{2}{*}{ No } & \multirow{2}{*}{$\begin{array}{c}\text { Ragam Keterampilan } \\
\text { Proses sains }\end{array}$} & \multicolumn{2}{|c|}{ Praktikum } & \multirow{2}{*}{$\begin{array}{l}\text { Rata } \\
\text { - Rata }\end{array}$} & \multirow[b]{2}{*}{ Kategori } \\
\hline & & $\begin{array}{c}\text { Sistem } \\
\text { Pencernaan }\end{array}$ & $\begin{array}{c}\text { Sistem } \\
\text { Pernapasan }\end{array}$ & & \\
\hline 1 & Mengamati/ Observasi & $71 \%$ & $74 \%$ & $73 \%$ & Cukup \\
\hline 2 & Mengelompokkan/ Klasifikasi & $57 \%$ & $57 \%$ & $57 \%$ & Kurang \\
\hline 3 & Menafsirkan/ Interpretasi & $69 \%$ & $68 \%$ & $69 \%$ & Cukup \\
\hline 4 & Meramalkan/ Memprediksi & $68 \%$ & $71 \%$ & $70 \%$ & Cukup \\
\hline 5 & Melakukan Komunikasi & $53 \%$ & $57 \%$ & $55 \%$ & Kurang \\
\hline 6 & Mengajukan pertanyaan & $83 \%$ & $83 \%$ & $83 \%$ & Baik \\
\hline 7 & Mengajukan Hipotesis & $67 \%$ & $67 \%$ & $67 \%$ & Cukup \\
\hline 8 & $\begin{array}{l}\text { Merencanakan percobaan atau } \\
\text { Penyelidikan }\end{array}$ & $79 \%$ & $79 \%$ & $79 \%$ & Baik \\
\hline 9 & $\begin{array}{l}\text { Menggunakan Alat, Bahan, atau } \\
\text { Sumber }\end{array}$ & $64 \%$ & $64 \%$ & $64 \%$ & Cukup \\
\hline 10 & Menerapkan Konsep & $69 \%$ & $58 \%$ & $64 \%$ & Cukup \\
\hline 11 & $\begin{array}{l}\text { Melakukan percobaan atau } \\
\text { Penyelidikan }\end{array}$ & $79 \%$ & $71 \%$ & $75 \%$ & Cukup \\
\hline & Rata-rata & uruhan & & $69 \%$ & Cukup \\
\hline
\end{tabular}

Data yang diperoleh pada hasil observasi ini memperlihatkan hasil tertinggi terletak pada indikator megajukan pertanyaan adalah $83 \%$ dengan kategori Baik dan indikator merencanakan percobaan/penyelidikan adalah $79 \%$ dengan kategori baik. Sementara indikator yang memperlihatkan hasil terendah yaitu pada indikator Mengelompokkan/ klasifikasi adalah 57\% dengan kategori Kurang dan indikator melakukan komunikasi adalaah 55\% dengan kategori Kurang sedangkan indikator yang lainnya yaitu indikator melakukan observasi adalah $73 \%$ dengan kategori cukup, indikator menafsirkan $69 \%$, indikator meramalkan/memprediksi $70 \%$, indikator mengajukan hipotesis $67 \%$, indikator menggunakan alat dan bahan serta sumber 64\%, indikator menerapkan konsep 64\% dan melakukan percobaan $75 \%$ dengan kategori Cukup. Jadi, berdasarkan hasil tersebut maka diperoleh rata-rata keseluruhan dari hasil observasi Keterampilan Proses Sains pada pelaksanaan praktikum biologi pada materi sistem pencernaan dan sistem pernapasan ini dalam kategori cukup dengan persentase 70\%. Berikut ini diagram hasil rekapitulasi data observasi pada pelaksanaan praktikum sistem pencernaan dan sistem pernapasan.

\section{a. Hasil Tes}


Rekapitulasi data hasil tes tiap indikator ketrampilan proses sains beserta persentasenya. Data yang diperoleh pada hasil tes ini memperlihatkan hasil tertinggi terletak pada indikator menerapkan konsep adalah $77 \%$ dengan kategori Baik dan indikator menggunakan alat dan bahan serta sumber adalah $77 \%$ dengan kategori Baik. Sedangkan pada indikator mengamati/mengobservasi adalah 73\%, indikator mengelompokan/mengklasifikasi adalah 63\%, indikator menafsirkan adalah 70\%, indikator meramalkan/memprediksi adalah $62 \%$, indikator mengajukan pertanyaan $63 \%$ dan merencanakan percobaan $68 \%$ dengan kategori Cukup. sedangkan indikator melakukan komunikasi adalah 59\% dengan kategori kurang dan yang memperlihatkan hasil terendah yaitu indikator mengajukan hipotesis yaitu $40 \%$ dengan kategori kurang sekali. Sehingga berdasarkan hasil tersebut maka diperoleh rata-rata keseluruhan dari hasil tes ini dalam kategori cukup dengan persentase $65 \%$.

Kemudian pada penelitian mengenai praktikum uji makanan dan praktikum mengukur udara pernapasan hewan mengenai keterampilan proses sains, selain menggunakan lembar observasi peneliti juga menggunakan soal tes pilihan ganda untuk mengetahui pemahaman konsep yang terdapat pada kedua praktikum yang sedang dilakukan, dimana tes pilihan ganda yang ada mewakili indikator-indikator yang ada pada keterampilan proses sains tersebut, Pengamatan dengan menggunakan tes pilihan ganda dilakukan setiap kali peserta didik selesai melakukan percobaan.

\section{b. Hasil Angket}

Rekapitulasi data Angket tiap indikator Sikap Ilmiah beserta persentasenya. Data yang diperoleh pada hasil angket ini memperlihatkan hasil tertinggi terletak pada indikator mengutamakan bukti adalah $81 \%$ dengan kategori Baik dan indikator menerima perbedaan adalah 79\% dengan kategori Baik, kemudian indikator Bersikap positif terhadap kegagalan adalah $77 \%$ dengan kategori baik, indikator Bersikap skeptis $76 \%$ dengan kategori baik, sedangkan indikator bekerja sama $74 \%$ dan indikator rasa ingin tahu $75 \%$ dengan kategori cukup. Sehingga berdasarkan hasil tersebut maka diperoleh rata-rata keseluruhan dari hasil angket ini dalam kategori baik dengan persentase $77 \%$. 


\begin{tabular}{llcccc}
\hline No & \multicolumn{1}{c}{ Indikator } & \multicolumn{2}{c}{ Materi } & $\begin{array}{c}\text { Rata- } \\
\text { Rata }\end{array}$ & Kategori \\
\cline { 3 - 5 } & & $\begin{array}{c}\text { Sistem } \\
\text { Pencernaan }\end{array}$ & $\begin{array}{c}\text { Sistem } \\
\text { Pernapasan }\end{array}$ & \\
\hline 1 & Rasa ingin tahu & $72 \%$ & $77 \%$ & $75 \%$ & Cukup \\
2 & Bekerja sama & $72 \%$ & $76 \%$ & $74 \%$ & Cukup \\
3 & Bersikap skeptis & $74 \%$ & $77 \%$ & $76 \%$ & Baik \\
4 & $\begin{array}{l}\text { Bersikap positif } \\
\text { terhadap kegagalan }\end{array}$ & $75 \%$ & $78 \%$ & $77 \%$ & Baik \\
5 & $\begin{array}{l}\text { Menerima perbedaan } \\
6\end{array}$ & $78 \%$ & $79 \%$ & $79 \%$ & Baik \\
Mengutamak an bukti & $80 \%$ & $81 \%$ & $81 \%$ & Baik \\
& \multicolumn{2}{c}{ Rata-rata Keseluuhan } & & $\mathbf{7 7 \%}$ & Baik \\
\hline
\end{tabular}

Hasil analisis deskriptif mengenai penerapan keterampilan proses sains melalui lembar observasi kegiatan praktikum uji makanan dan mengukur udara pernapasan hewan mengungkapkan temuan hasil penelitian bahwa pada indikator mengajukan pertanyaan memperoleh persentase tertinggi yaitu $83 \%$ dengan kategori baik, sedangkan pada indikator melakukan komunikasi memperoleh hasil terendah yaitu 55\% dengan kategori kurang. Berdasarkan analisis data secara keseluruhan dari hasil penelitian menunjukkan penerapan keterampilan proses sains pada pelaksanaan praktikum Biologi materi sistem pencernaan dan sistem pernapasan terhadap peserta didik di SMA Al-Azhar 3 Bandar Lampung adalah dengan kategori cukup. Kemudian pada analisis data yang berikutnya yaitu mengenai pemahaman ketrampilan proses sains peserta didik terhadap konsep materi pada pelaksanaan praktikum juga mendapatkan kategori cukup. Sedangkan pada penerapan sikap ilmiah pada pelaksanaan praktikum mendapakan kategori baik.

Kendala yang terjadi selama pelaksanaan penelitian pada praktikum uji makanan dan mengukur udara pernapasan bukanlah suatu kendala yang serius, seperti beberapa peserta didik yang tidak fokus pada saat pelaksanaan praktikum sedang berlangsung, peserta didik yang asik mengobrol dengan teman satu kelompoknya, dan lain sebagainya dapat diatasi, karena selama penelitian peneliti didampingi dan dibantu oleh asisten praktikum yang sedang bertugas. Secara keseluruhan tahapan-tahapan penelitian yang menjadi penilaian pada lembar observasi keterampilan proses sains dan soal tes pilihan ganda keterampilan proses sains serta angket sikap ilmiah berjalan dengan lancar.

Hasil respon peserta didik juga mendukung diterapkannya penilaian pada pendekatan keterampilan proses sains, alasannya pendekatan ini mampu memberikan motivasi peserta didik dalam menggali ilmu pengetahuan, membangkitkan minat belajar 
peserta didik dalam pelaksanaan praktikum, dan meningkatkan keterampilan proses sains serta sikap ilmiah peserta didik. Keterampilan proses sains akan terbentuk hanya melaui peroses yang berulang-ulang. Hasil penelitian menunjukkan respon peserta didik dan tanggapan peserta didik mengenai penerapan pendekatan keterampilan proses sains dan sikap ilmiah pada pelaksanaan praktikum menyatakan peserta didik merasa tertarik dan senang, membuat peserta didik lebih mudah memahami jalannya praktikum, alat, bahan serta sumber yang digunkan, sampai pada menyimpulkan hasil penelitian yang akan disampaikan kepada teman satu kelompok dan kepada kelompok lainnya. Menerapkan keterampilan proses sains dan sikap ilmiah peserta didik akan mampu menemukan dan mengembangkan sendiri fakta dan konsep serta menumbuhkan dan mengembangkan nilai yang dituntut.

Berdasarkan lembar observasi yang digunakan untuk menilai keterampilan proses sains pada pelaksanaan praktikum dilakukan pada materi sistem pencernaan dan sistem pernapasan, Keterampilan Proses Sains yang sering muncul atau sering terlaksana oleh peserta didik yaitu mengajukan pertanyaan, mengamati/observasi, merencanakan percobaan serta melakukan percobaan, sedangkan Sikap Ilmiah yang sering muncul yaitu mengutamakan bukti, menerima perbedaan dan bersikap positif terhadap kegagalan. Dimana hubungan dari Keterampilan Proses Sains dan Sikap Ilmiah didalam pengamatan yang dilakukan peneliti adalah sikap ilmiah sangat berpengaruh dalam Keterampilan Proses Sains yang ada pada peserta didik. Karena pembelajaran sains bukan hanya transfer ilmu namun sebuah proses yang memfasilitasi siswa unuk melatih keerampilan, membangun kemampuan kognitifnya dan menumbuhkan sikap posiif.

\section{KESIMPULAN DAN SARAN}

Berdasarkan lembar observasi yang digunakan untuk menilai keterampilan proses sains pada pelaksanaan praktikum dilakukan pada materi sistem pencernaan dan sistem pernapasan, Keterampilan Proses Sains yang sering muncul atau sering terlaksana oleh peserta didik yaitu mengajukan pertanyaan, mengamati/observasi, merencanakan percobaan serta melakukan percobaan yang menunjukkan penerapan Keterampilan Proses Sains pada pelaksanaan praktikum tersebut tergolong kedalam kategori cukup. Kemudian berdasarkan angket yang digunakan indikator Sikap Ilmiah yang sering muncul yaitu mengutamakan bukti, menerima perbedaan dan bersikap positif terhadap kegagalan. yang menunjukkan penerapan Sikap Ilmiah pada pelaksanaan praktikum tersebut tergolong kedalam kategori Baik. Hubungan dari Keterampilan Proses Sains dan Sikap Ilmiah didalam pengamatan 
yang dilakukan peneliti adalah sikap ilmiah sangat berpengaruh dalam Keterampilan Proses Sains yang ada pada peserta didik.

Saran yang dapat diberikan berdasarkan hasil penelitian bahwa setiap guru biologi dalam mengajar diharapkan lebih memperhatikan keterapilan proses sains dan sikap ilmiah peserta didiknya. Karena tantangan masa depan kedua hal tersebut sangat dibutuhkan dalam kehidupan sehari-hari.

\section{DAFTAR PUSTAKA}

Arumsari, Lusia Tiara, Ila Rosilawati, dan Nina Kadaritna. 2016. "Pengembangan Instrumen Asesmen Keterampilan Proses Sains Pada Materi Teori Tumbukan.” Jurnal Pendidikan dan Pembelajaran Kimia 5 (1): 140-51.

Karyanti, Karyanti, dan Komarudin Komarudin. 2017. "Pengaruh Model Pembelajaran Kumon Terhadap Pemahaman Matematis Ditinjau Dari Gaya Kognitif Peserta Didik Pada Mata Pelajaran Matematika Kelas Viii Smp Negeri Satu Atap 4 Pesawaran.” Dalam Prosiding Seminar Nasional Matematika dan Pendidikan Matematika, 1:8994.

Marlina, Reni. 2013. "Pemanfaatan Lingkungan Lokal dalam Kegiatan Laboratorium Berbasis Inkuiri Terhadap Sikap Ilmiah Mahasiswa Calon Guru Biologi.” Jurnal Visi Ilmu Pendidikan 10 (1).

Mintania, Fesy, Muhammad Su'aidy, dan I. Wayan Dasna. 2013. "Penerapan metode inkuiri terbimbing untuk meningkatkan hasil belajar dan sikap ilmiah siswa kelas XI IPA semester II SMA Negeri 5 Malang pada materi pokok koloid." SKRIPSI Jurusan Kimia-Fakultas MIPA UM.

Novitasari, Aulia, Alinis Ilyas, dan Siti Nurul Amanah. 2017. "Pengaruh Model Pembelajaran Inkuiri Terbimbing Terhadap Keterampilan Proses Sains Peserta Didik Pada Materi Fotosintesis Kelas XII IPA Di SMA Yadika Bandar Lampung." Biosfer: Jurnal Tadris Biologi 8 (1): 91-104.

Puspita, Laila, Nanang Supriadi, dan Amanda Diah Pangestika. 2018. "Pengaruh Model Pembelajaran Creative Problem Solving (CPS) Disertai Teknik Diagram Vee Terhadap Keterampilan Berpikir Kreatif Peserta Didik Materi Fungi Kelas X Man 2 Bandar Lampung.” Biosfer: Jurnal Tadris Biologi 9 (1): 01-12.

Puspita, Laila, Yetri Yetri, dan Ratika Novianti. 2017. "Pengaruh Model Pembelajaran Reciprocal Teaching Dengan Teknik Mind Mapping Terhadap Kemampuan Metakognisi Dan Afektif Pada Konsep Sistem Sirkulasi Kelas Xi Ipa Di Sma Negeri 15 Bandar Lampung." Biosfer: Jurnal Tadris Biologi 8 (1): 78-90.

Rustaman, Nuryani, Soendjojo Dirdjosoemarto, Surosos Adi Yudianto, Yusnani Achmad, Ruchji Subekti, Diana Rochintaniawati, dan M. Nurjhani. 2005. Strategi belajar mengajar biologi. Malang: UM Press.

Saputra, Indra Dodo, Sri Anggraeni, dan Bambang Supriatno. 2016. "Implementasi Pendekatan Konstruktivisme pada Pembelajaran Biologi dalam Meningkatkan 
Kemampuan Literasi Kuantitatif dan Sikap Ilmiah Siswa SMA pada Materi Pencemaran Lingkungan." Dalam Proceeding Biology Education Conference: Biology, Science, Enviromental, and Learning, 13:249-54.

Septina, Nora, Farida Farida, dan Komarudin Komarudin. 2018. "Pengembangan Lembar Kerja Siswa Dengan Pendekatan Saintifik Berbasis Kemampuan Pemecahan Masalah.” Jurnal Tatsqif 16 (2): 160-71. https://doi.org/10.20414/jtq.v16i2.200.

Sukaesih, Sri. 2011. “Analisis sikap ilmiah dan tanggapan mahasiswa terhadap penerapan model pembelajaran berbasis praktikum.” Jurnal penelitian pendidikan 28 (1). 